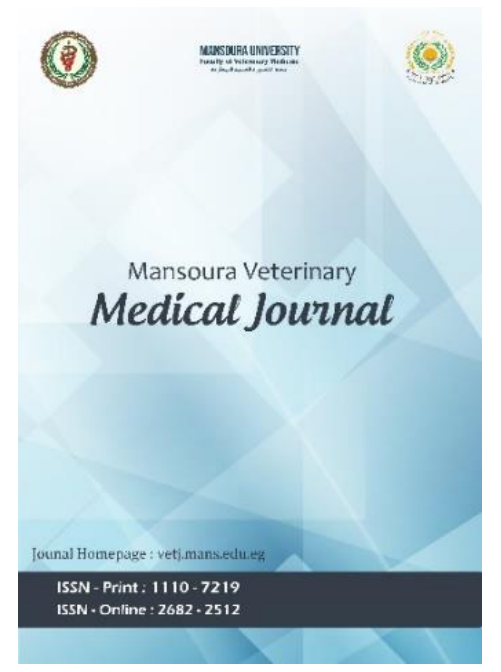

Effect of pollution with lead, cupper, cadmium on gene expression pattern of liver GST and serum lysozymes in Nile tilapia (Oreochromis. niloticus)

Enas Hassan, Gehad El-sayed, Azza Hassan, Shimaa Abd Elsalam

To cite this article: Enas Hassan, Gehad El-sayed, Azza Hassan, Shimaa Abd Elsalam. Effect of pollution with lead, cupper, cadmium on gene expression pattern of liver GST and serum lysozymes in Nile tilapia (Oreochromis. niloticus). Mansoura Veterinary Medical Journal 2020; 21, 3: 53-60.

To link to this article: https://doi.org/10.35943/mvmj.2020.310

Published online: 29 September 2020

Submit your article to this journal

CrossMark data 


\section{Effect of pollution with lead, cupper, cadmium on gene expression pattern of liver GST and serum lysozymes in Nile tilapia (Oreochromis. niloticus)}

Enas Hassan, Gehad El-sayed, Azza Hassan, Shimaa Abd Elsalam

Department of Biochemistry and Chemistry of Nutrition, Faculty of Veterinary Medicine, Mansoura University

\section{ARTICLE HISTORY}

Received: 26.03 .2020

Revised: 03.07.2020

Accepted: 10.07 .2020

Address correspondence to Enas Hasan; Tel: +201064317314; E-mail: enashassan110@gmail.com

\section{ABSTRACT}

\begin{abstract}
Objective: This study was conducted to evaluate the influence of pollution with lead, copper, cadmium on the gene expression pattern of liver Glutathione-S-transferase and serum lysozyme in Nile tilapia (Oreochromis. niloticus).

Design: Descriptive study.

Fish: A Total of 120 Nile tilapia fish (Oreochromis niloticus) samples were collected from Lake Manzala, and drainage water at different localities.

Procedures: lead, copper and cadmium concentrations within mid-dorsal muscle tissue, within gills, liver, and kidney were determined. Erythrocyte count, hemoglobin concentration, Packed Cell volume and other blood indices, as well as, total leukocyte count were measured. Biochemically, Alanine transaminase, Aspartate transaminase activities, total protein, creatinine, uric acid, lysozymes activity were estimated. GST gene expression was determined in the liver.

Results: The results showed that $\mathrm{Pb}, \mathrm{Cu}$ and $\mathrm{Cd}$ were bio accumulated at a higher level in the liver, kidney and gills of Nile tilapia fish (Oreochromis niloticus) from all sampling sites. The activities of ALT and AST were increased significantly $(p<0.05)$, but total protein and Albumin concentrations were decreased. Creatinine and uric acid were significantly increased in all groups compared to the control group ( $P \leq 0.05)$. Hematological parameters and lysozyme activity were decreased. Up regulation of the hepatic GST expression levels in Nile tilapia exposed to the heavy metals in comparis on to the control value.

Conclusion and clinical relevance: This study shows that lead, copper and cadmium were bio accumulated at higher concentration in liver, kidney, gills and muscles of Nile tilapia due to large industrial activities near locations of the sampling sites. Additionally, GST gene expression represents sensitive biomarker of aquatic pollution.
\end{abstract}

Keywords: Heavy metals, pollution, Nile tilapia.

\section{INTRODUCTION}

Fish are mainly susceptible and severely affected by pollution as they couldn't avoid harmful influences of pollutants because of feeding and existing within aquatic system [1]. Fish, compared to invertebrates, are further liable to numerous toxic agents and are good models for evaluating the

Eecosystem health [2]. Heavy metals are formed from different natural and anthropogenic sources [3]. In the aquatic system, heavy metal pollution caused by direct atmos pheric accumulation, geologic weathering or via the discharge of agricultural, municipal, residential or industrial waste products, by WWTPs [2]. Coal combustion is one of the commonest anthropogenic emission sources of trace elements and a significant source of numerous metals [4].
Contamination by heavy metals and metalloids in water and sediment, if existing within high levels, is a significant danger due to their toxicity, durability, and deposition and biomagnification within food chain [5]. Fish are regarded to become most significant bio-monitors in the aquatic system for evaluation of heavy metal pollution [2], they provide many particular benefits in illustrating natural properties of a quatic systems and in evaluating va riations to habitats [6]. Beside fish exist within the end of the aquatic food chain and can store heavy metals and transfer it to human via food leading to different disorders [7] .

It is reported that heavy metals residues within the tissues are mostly reliant upon their level in the water and the exposure period; however, some other environmental factors like water temperature, oxygen concentration, $\mathrm{pH}$, hardness, salinity, alkalinity and dissolved organic carbon can be implicated in heavy metals bioaccumulation and toxicity in 
fish. Ecol ogical needs, size and age of individuals, their life cycle, feeding habits, and season of capture were known to influence experimental outcomes from tissues [8]. Fish can uptake and concentrate heavy metals directly via surrounding water or indirectly from other organisms like small fish, invertebrates, and aquatic vegetation [8]. Fish bioaccumulate pollutants, es pecially in their fatty tissues such as liver [9]. Though, this bioaccumulation relies on their intake, storage, and elimination from the body [2]. This indicates that subjected to high uptake and low elimination rates within fish tissues could become stored at higher concentrations [10]. Fish uptake heavy metals via the ingestion of contaminated food by GIT or gills and skin [11]. Following absorption, are transported across the blood strea $m$ to organs and tissues in which deposition occurs [12]. Heavy metal levels within fish tissues refer to previous exposure through water and/or food and it could show the existing condition of a nimals before toxicity influences the ecological balance of populations within the aquatic system [13].

The main objective of this study is to know the effect of some heavy metals pollution on organs of Nile tilapia Fish in Delta. We determined the cadmium, copper, and lead in muscles, gills, liver, and kidney of Nile Tilapia fish (Oreochromis spp)

\section{MATERIALS AND METHODS}

\subsection{Fish}

A total of 120 Nile tilapia fish were collected from all sampling sites. . Entire body length mea suring $(20 \pm 2 \mathrm{~cm})$ and to exclude differences caused by variations of stomach fullness net BW (eviscerated) $(200 \pm 20 \mathrm{~g})$.

\subsection{Study design}

One hundred and twenty fish samples (Orechromis.niloticus) were collected from six localities in Egypt, na med Kafr Elsheik, drainage behind Talkha factory of fertilization, Elgerby Ras Elbar, Manzala Lake, Nile branch at Sherbin ( 20 each).

\subsection{Collection of the blood samples}

Following capture, Nile tilapia fish were apparently healthy (i.e., absence of manifestations of abnormalities or infestation). Blood collection was performed on spot with the help of fishermen, via venipuncture of caudal vein by sterile plastic syringe $(2.5 \mathrm{~mL})$ and transported to two tubes, the first one contained $1.26 \mathrm{mg}$ of ethylene dia mine tetra a cetic acid (EDTA) as anticoagulant substance; for hematological analysis. The other tube was plain one for serum separation; it was centrifuged for ten minutes at $3000 \mathrm{rpm} / \mathrm{min}$, then serum was obtained and stored at $4{ }^{\circ} \mathrm{C}$ until biochemical and lysozyme analysis. Fish then were transported to the laboratory within same day and Biosafety measures were taken. Fish were immediately dissected to remove liver, kidney, gills and muscles, for bioaccumulation and gene expression analysis.

\section{4 .Hematological analysis}

All hematological samples were evaluated via same technique upon to Fazio The blood samples collected in EDTA tubes were used for the determination of hematological profile using a n a utomated hematology analyzer (HeCo Vet C, SEAC, Florence, Italy)with special lysing reagent for fish (SEAC, Code 71010460), previously used to investigate hematological profile in Tilapia fish [12]. Assessment of hemogram, including of Red blood cell (RBC), White blood cells (WBC) counts, Packed cell volume (PCV), hemoglobin Hb, Mean corpuscular hemoglobin (MCH) ,Mean corpuscular volume (MCV), mean corpuscular hemoglobin (MCHC) was included.

\subsection{Dissection of fish}

The first part of liver, gills, muscle and kidneys are put within aluminum foil and stored at 4 degree for quantitative detection of heavy metals in these organs. However, the second part of liver is immediately minced into small pieces using sharp clean scalpel blade, inserted in eppindorf tube containing RNA later and stored as soon as possible at $-80 \mathrm{C}$ for determination of some heavy metals gene expression using semi qualitative polymerase chain reaction which was performed under complete aseptic condition.

Determination of heavy metals within liver, kidney, muscle and gills of fish (O (Oreochromis niloticus) according to the methods described previously [14-15]

\subsection{Heavy Metals}

Cadmium, copper and lead were es timated in the tissues according to standard method [16].

\subsection{Gene expression pattern of GST in liver tissue}

Acceding to a standard technique [17], the gene expression pattern of GST was determined. Amplification curves and ct values were determined by the stratagene MX3005P software. To estimate the variation of gene expression on the RNA of the different samples, the CT of each sample was compared with that of the control group a ccording to the " $\Delta \Delta \mathrm{Ct}$

\subsection{Serum lysozyme activity}

Lysozyme activity of Nile tilapia (Oreochromis niloticus) serum was obtained via means of turbid metric assay upon [18]

\subsection{Statistical Analysis}

All data are statistically analyzed by statistical software program (SPSS for windows, version 20, USA). Data were expressed as means \pm standard error. .ANOVA was used to know differences between means of all groups with post hoc Duncan multiple comparison tests. Difference results were considered a significant when $p \leq 0.05$ [19]

\section{RESULTS}

The results of the present study are summarized in tables 1-8. $\mathrm{Pb}, \mathrm{Cu}$ and $\mathrm{Cd}$ were bio accumulated at 
a higher level in the liver, kidney and gills of Nile tilapia fish from all sampling sites. The levels of the ALT and AST were increased, total protein and Albumin concentrations were decreased. Creatinine and uric acid were significantly $(P \leq 0.05)$ increased in all groups compared to the control. Hematological parameters and lysozyme activity were decreased. Up regulation of the hepatic GST expression levels in Nile tilapia exposed to the heavy metals in comparison to the control value.

Table 1. Level of lead in Muscle,Liver, Kidney, and Gills) of Nile Tilapia fish in different localities in Delta region, Egypt ((ppm/gm, Mean \pm S.E).

\begin{tabular}{|c|c|c|c|c|c|c|}
\hline Group & $\begin{array}{l}\text { Control group } \\
\text { (speial farm from } \\
\text { Kafr Elsheik) } \\
\text { (G1) }\end{array}$ & $\begin{array}{l}\text { Talkha } \\
\text { Drainage } \\
\text { (G2) }\end{array}$ & $\begin{array}{l}\text { Elgerpy in } \\
\text { Ras Elbar } \\
\text { (G3) }\end{array}$ & $\begin{array}{l}\text { Manzala } \\
\text { Lake } \\
\text { (G4) }\end{array}$ & $\begin{array}{l}\text { Nile of } \\
\text { Sherbin } \\
\text { (G5) }\end{array}$ & $\begin{array}{l}\text { Diast } \\
\text { Drainage } \\
\text { (G6) }\end{array}$ \\
\hline Muscles & $\begin{array}{l}0.03 \pm \\
0.001^{d}\end{array}$ & $\begin{array}{l}10.37 \pm \\
.059^{a}\end{array}$ & $\begin{array}{l}0.62 \\
\pm 0.010^{c}\end{array}$ & $\begin{array}{l}0.87 \\
\pm 0.046^{b}\end{array}$ & $\begin{array}{l}0.61 \pm \\
0.038^{c}\end{array}$ & $\begin{array}{l}0.451 \pm \\
0.049^{c d}\end{array}$ \\
\hline liver & $\begin{array}{l}0.023 \pm \\
0.001^{\mathrm{e}}\end{array}$ & $\begin{array}{l}1.09 \pm \\
\pm 0.059 \text { a }\end{array}$ & $\begin{array}{l}0.56 \\
\pm 0.014^{b c}\end{array}$ & $\begin{array}{l}0.70 \\
\pm 0.016^{b}\end{array}$ & $\begin{array}{l}0.37 \\
\pm 0.064^{d}\end{array}$ & $\begin{array}{l}0.451 \pm \\
0.049^{c d}\end{array}$ \\
\hline kidney & $\begin{array}{l}0.028 \pm \\
0.0013^{e}\end{array}$ & $\begin{array}{l}1.26 \\
\pm 0.03^{a}\end{array}$ & $\begin{array}{l}0.51 \\
\pm 0.004^{c}\end{array}$ & $\begin{array}{l}0.72 \pm \\
0.038^{b}\end{array}$ & $\begin{array}{l}0.27 \pm \\
0.058^{d}\end{array}$ & $\begin{array}{l}0.336 \\
\pm 0.064^{c d}\end{array}$ \\
\hline Gills & $\begin{array}{l}0.031 \pm \\
0.001^{d}\end{array}$ & $\begin{array}{l}1.13 \\
\pm 0.074^{a}\end{array}$ & $\begin{array}{l}0.67 \\
\pm 0.020^{b c}\end{array}$ & $\begin{array}{l}0.77 \pm \\
0.038^{b}\end{array}$ & $\begin{array}{l}0.56 \pm \\
0.032^{c}\end{array}$ & $\begin{array}{l}0.602 \\
\pm 0.069 b c\end{array}$ \\
\hline
\end{tabular}

Means in the same row with different superscripts are significantly different at $(P \leq 0.05)$.

Table 2 level of cadmium in Muscles,Liver, Kidney, and Gills) of Nile Tilapia fish in different localities in Delta region, Egypt (p pm/gm, Mean \pm S.E).

\begin{tabular}{|c|c|c|c|c|c|c|}
\hline Organ & $\begin{array}{l}\text { Control group } \\
\text { (speial farm from } \\
\text { Kafr Elsheik) } \\
\text { (G1) }\end{array}$ & $\begin{array}{l}\text { Talkha } \\
\text { Drainage } \\
\text { (G2) }\end{array}$ & $\begin{array}{l}\text { Elgerpy in } \\
\text { Ras Elbar } \\
\text { (G3) }\end{array}$ & $\begin{array}{c}\text { Manzala } \\
\text { Lake } \\
\text { (G4) }\end{array}$ & $\begin{array}{l}\text { Nile of Sherbin } \\
\text { (G5) }\end{array}$ & $\begin{array}{c}\text { Diast } \\
\text { Drainage } \\
\text { (G6) }\end{array}$ \\
\hline Muscles & $\begin{array}{l}0.03 \pm \\
0.001^{c}\end{array}$ & $\begin{array}{l}0.09 \\
\pm 0.009 a\end{array}$ & $\begin{array}{l}0.06 \\
\pm 0.0023^{b}\end{array}$ & $\begin{array}{l}0.069 \pm \\
0.01^{b}\end{array}$ & $\begin{array}{l}0.053 \pm \\
0.0028^{b c}\end{array}$ & $\begin{array}{l}0.065 \pm \\
0.004^{b}\end{array}$ \\
\hline Liver & $\begin{array}{l}0.05 \pm \\
0.003^{c}\end{array}$ & $\begin{array}{l}0.15 \\
\pm 0.0086^{a}\end{array}$ & $\begin{array}{l}0.07 \\
\pm 0.01^{b}\end{array}$ & $\begin{array}{l}0.089 \pm \\
0.01^{b}\end{array}$ & $\begin{array}{l}0.069 \pm \\
0.004^{b c}\end{array}$ & $\begin{array}{l}0.086 \pm \\
0.01^{b}\end{array}$ \\
\hline Kidney & $\begin{array}{l}0.03 \\
\pm 0.002^{d}\end{array}$ & $\begin{array}{l}0.10 \\
\pm 0.0074^{a}\end{array}$ & $\begin{array}{l}0.08 \\
\pm 0.01^{\mathrm{ab}}\end{array}$ & $\begin{array}{l}0.086 \pm \\
0.003 a b\end{array}$ & $\begin{array}{l}0.063 \pm \\
0.0039 c\end{array}$ & $\begin{array}{l}0.078 \pm \\
0.01^{b c}\end{array}$ \\
\hline Gills & $\begin{array}{l}0.03 \\
\pm 0.001^{c}\end{array}$ & $\begin{array}{l}0.10 \\
\pm 0.0099^{a}\end{array}$ & $\begin{array}{l}0.058 \\
\pm 0.01^{b}\end{array}$ & $\begin{array}{l}0.061 \pm \\
0.003^{b}\end{array}$ & $\begin{array}{l}0.058 \pm \\
0.0035^{b}\end{array}$ & $\begin{array}{l}0.055 \\
\pm 0.01^{b c}\end{array}$ \\
\hline
\end{tabular}

Means in the same row with different superscripts are significantly different at $(P \leq 0.05)$.

Table 5: Effect of heavy metals pollution on the Indicative biomarkers of liver functions of Nile tila pia fish in different localities of delta Egypt.

\begin{tabular}{|c|c|c|c|c|c|c|}
\hline Parameters & $\begin{array}{l}\text { Control group } \\
\text { (special farm } \\
\text { from } \\
\text { Kafr Elsheik) }\end{array}$ & $\begin{array}{l}\text { Talkha } \\
\text { Drainage } \\
\text { (G2) }\end{array}$ & $\begin{array}{l}\text { Elgerpy in } \\
\text { Ras Elbar } \\
\text { (G3) }\end{array}$ & $\begin{array}{l}\text { Manzala } \\
\text { Lake } \\
\text { (G4) }\end{array}$ & $\begin{array}{l}\text { Nile of } \\
\text { Sherbin } \\
\text { (5) }\end{array}$ & $\begin{array}{l}\text { Diast } \\
\text { Drainage } \\
\text { (G6) }\end{array}$ \\
\hline ALT & 8.45 & 12.88 & 10.34 & 11.61 & 9.59 & 10.74 \\
\hline (u/I) & $\pm 0.15^{e}$ & $\pm 0.09^{a}$ & $\pm 0.24^{c}$ & $\pm 0.19^{b}$ & $\pm 0.14^{d}$ & $\pm 0.18^{c}$ \\
\hline $\begin{array}{l}\text { AST } \\
\text { (v/I) }\end{array}$ & $\begin{array}{l}263.89 \\
\pm 1.50^{\mathrm{e}}\end{array}$ & $\begin{array}{l}290.95 \\
\pm 1.84^{a}\end{array}$ & $\begin{array}{l}272.11 \\
\pm 1.25^{\mathrm{cd}}\end{array}$ & $\begin{array}{l}278.34 \\
\pm 1.63^{b}\end{array}$ & $\begin{array}{l}269.12 \\
\pm 1.42^{\text {de }}\end{array}$ & $\begin{array}{l}275.78 \\
\pm 1.53^{\text {bc }}\end{array}$ \\
\hline $\begin{array}{l}\text { Total Proteins } \\
\text { (gm/dl) }\end{array}$ & $\begin{array}{l}4.18 \\
\pm 0.44^{a}\end{array}$ & $\begin{array}{l}3.28 \\
\pm 0.38^{c}\end{array}$ & $\begin{array}{l}3.57 \\
\pm 0.38^{b c}\end{array}$ & $\begin{array}{l}3.41 \\
\pm 0.301^{b c}\end{array}$ & $\begin{array}{l}3.96 \\
\pm 0.38^{\mathrm{ab}}\end{array}$ & $\begin{array}{l}3.57 \\
\pm 0.42^{b c}\end{array}$ \\
\hline $\begin{array}{l}\text { Albumin } \\
\text { (gm/dl) }\end{array}$ & $\begin{array}{l}3.12 \\
\pm 0.12^{a}\end{array}$ & $\begin{array}{l}2.44 \\
\pm 0.05^{c}\end{array}$ & $\begin{array}{l}2.76 \\
\pm 0.09 \mathrm{bc}\end{array}$ & $\begin{array}{l}2.54 \\
\pm 0.05^{c}\end{array}$ & $\begin{array}{l}2.92 \\
\pm 0.08^{a b}\end{array}$ & $\begin{array}{l}2.60 \\
\pm 0.07^{b c}\end{array}$ \\
\hline
\end{tabular}


Table 3: level of copper in Muscles,Liver, Kidney, and Gills) of Nile Tilapia fish in different localities in Delta region, Egypt ((ppm/gm, Mean \pm S.E).

\begin{tabular}{|c|c|c|c|c|c|c|}
\hline Organ & $\begin{array}{l}\text { Control group } \\
\text { (speial farm } \\
\text { from Kafr } \\
\text { Elsheik) } \\
\text { (G1) }\end{array}$ & $\begin{array}{l}\text { Talkha } \\
\text { Drainage } \\
\text { (G2) }\end{array}$ & $\begin{array}{l}\text { Elgerpy in } \\
\text { Ras Elbar } \\
\text { (G3) }\end{array}$ & $\begin{array}{l}\text { Manzala } \\
\text { Lake } \\
\text { (G4) }\end{array}$ & $\begin{array}{l}\text { Nile of } \\
\text { Sherbin } \\
\text { (G5) }\end{array}$ & $\begin{array}{l}\text { Diast Drainage } \\
\text { (G6) }\end{array}$ \\
\hline Muscles & $\begin{array}{l}0.033 \\
\pm 0.003^{c}\end{array}$ & $\begin{array}{l}0.84 \\
\pm 0.022^{a}\end{array}$ & $\begin{array}{l}0.52 \\
\pm 0.0049 b\end{array}$ & $\begin{array}{l}0.52 \pm \\
0.022^{b}\end{array}$ & $\begin{array}{l}0.54 \\
\pm 0.0195^{b}\end{array}$ & $\begin{array}{l}0.48 \pm \\
0.024^{b}\end{array}$ \\
\hline liver & $\begin{array}{l}0.24 \pm \\
0.025^{d}\end{array}$ & $\begin{array}{l}1.15 \\
\pm 0.079^{a}\end{array}$ & $\begin{array}{l}0.75 \\
\pm 0.009^{b}\end{array}$ & $\begin{array}{l}0.54 \\
\pm 0.015^{c}\end{array}$ & $\begin{array}{l}0.53 \pm \\
0.019 c\end{array}$ & $\begin{array}{l}0.52 \pm \\
0.019 c\end{array}$ \\
\hline kideny & $\begin{array}{l}0.031 \\
\pm 0.039^{d}\end{array}$ & $\begin{array}{l}1.18 \\
\pm 0.067^{a}\end{array}$ & $\begin{array}{l}0.62 \\
\pm 0.016^{c}\end{array}$ & $\begin{array}{l}0.67 \\
\pm 0.034^{b}\end{array}$ & $\begin{array}{l}0.56 \pm \\
0.032^{c}\end{array}$ & $\begin{array}{l}0.651 \\
\pm 0.036^{b}\end{array}$ \\
\hline gills & $\begin{array}{l}0.038 \\
\pm 0.002^{b}\end{array}$ & $\begin{array}{l}0.53 \\
\pm 0.047^{a}\end{array}$ & $\begin{array}{l}0.56 \\
\pm 0.0056^{a}\end{array}$ & $\begin{array}{l}0.57 \\
\pm 0.073^{a}\end{array}$ & $\begin{array}{l}0.524 \pm \\
0.0091^{a}\end{array}$ & $\begin{array}{l}0.45 \\
\pm 0.014^{a}\end{array}$ \\
\hline
\end{tabular}

Means in the same row with different superscripts are significantly different at $(P \leq 0.05)$.

Table 4. Effect of heavy metals pollution on different Hematological parameters in different localities of delta Egypt.

\begin{tabular}{|c|c|c|c|c|c|c|}
\hline Parameter & $\begin{array}{l}\text { Control } \\
\text { group/(speial } \\
\text { farm from Kafr } \\
\text { Elsheik)(G1) }\end{array}$ & $\begin{array}{l}\text { Talkha } \\
\text { Drainage } \\
\text { (G2) }\end{array}$ & $\begin{array}{l}\text { Elgerpy in } \\
\text { Ras Elbar } \\
\text { (G3) }\end{array}$ & $\begin{array}{l}\text { Manzala } \\
\text { Lake } \\
(\mathrm{G} 4)\end{array}$ & $\begin{array}{l}\text { Nile of } \\
\text { Sherbin } \\
\text { (G5) }\end{array}$ & $\begin{array}{l}\text { Diast } \\
\text { Drainage } \\
\text { (G6) }\end{array}$ \\
\hline 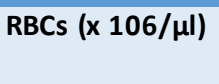 & $\begin{array}{l}1.92 \\
\pm 0.03 a\end{array}$ & $\begin{array}{l}1.37 \\
\pm 0.03 d\end{array}$ & $\begin{array}{l}1.56 \\
\pm 0.026 c\end{array}$ & $\begin{array}{l}1.48 \\
\pm 0.022 \mathrm{c}\end{array}$ & $\begin{array}{l}1.67 \\
\pm 0.031 b\end{array}$ & $\begin{array}{l}1.59 \\
\pm 0034 c\end{array}$ \\
\hline $\mathrm{HB}(\mathrm{g} / \mathrm{dl})$ & $\begin{array}{l}6.88 \\
\pm 0.16 a\end{array}$ & $\begin{array}{l}4.72 \\
\pm 0.14 d\end{array}$ & $\begin{array}{l}5.69 \\
\pm 0.13 \mathrm{c}\end{array}$ & $\begin{array}{l}4.90 \pm \\
0.126 d\end{array}$ & $\begin{array}{l}6.63 \\
\pm 0.14 \mathrm{ab}\end{array}$ & $\begin{array}{l}6.28 \\
\pm 0.12 \mathrm{~b}\end{array}$ \\
\hline $\mathrm{MCH}$ & $\begin{array}{l}35.71 \\
\pm 0.46\end{array}$ & $\begin{array}{l}34.43 \\
\pm 0.38\end{array}$ & $\begin{array}{l}36.43 \\
8 \pm 0.33\end{array}$ & $\begin{array}{l}33.05 \\
\pm 0.28\end{array}$ & $\begin{array}{l}39.53 \\
\pm 0.37\end{array}$ & $\begin{array}{l}39.50 \\
\pm 0.63\end{array}$ \\
\hline MCV & $\begin{array}{l}127.00 \\
\pm 2.25\end{array}$ & $\begin{array}{l}132.26 \\
\pm 2.46\end{array}$ & $\begin{array}{l}134.69 \\
\pm 3.11\end{array}$ & $\begin{array}{l}132.32 \\
\pm 2.68\end{array}$ & $\begin{array}{l}133.67 \\
\pm 2.8\end{array}$ & $\begin{array}{l}128.90 \\
\pm 3.1\end{array}$ \\
\hline $\mathrm{MCHC}$ & $\begin{array}{l}28.12 \\
\pm 0.55\end{array}$ & $\begin{array}{l}26.03 \\
\pm 0.43\end{array}$ & $\begin{array}{l}27.05 \\
\pm 0.46\end{array}$ & $\begin{array}{l}24.97 \\
\pm 0.32\end{array}$ & $\begin{array}{l}29.57 \\
\pm 0.37\end{array}$ & $30.64 \pm 0.33$ \\
\hline PCV\% & $\begin{array}{l}24.48 \\
\pm 0.38 a\end{array}$ & $\begin{array}{l}18.13 \\
\pm 0.16 \mathrm{c}\end{array}$ & $\begin{array}{l}21.06 \\
\pm 0.42 b\end{array}$ & $\begin{array}{l}19.65 \\
\pm 0.17 \mathrm{c}\end{array}$ & $\begin{array}{l}22.44 \\
\pm 0.26 a\end{array}$ & $\begin{array}{l}20.50 \\
\pm 0.28 \mathrm{~b}\end{array}$ \\
\hline $\begin{array}{l}\text { WBCs } \\
(x 103 / \mu \mathrm{l})\end{array}$ & $\begin{array}{l}41.88 \\
\pm 0.44\end{array}$ & $\begin{array}{l}32.82 \\
\pm 0.38 d\end{array}$ & $\begin{array}{l}35.78 \\
\pm 0.38 \mathrm{c}\end{array}$ & $\begin{array}{l}34.17 \\
\pm 0.30 \mathrm{~d}\end{array}$ & $\begin{array}{l}39.67 \\
\pm 0.38 \mathrm{~b}\end{array}$ & $\begin{array}{l}35.76 \\
\pm 0.42 \mathrm{c}\end{array}$ \\
\hline Lymphocyte (\%) & $65.4 \pm 2.53$ & $56.42 \pm 1.67$ & $58.22 \pm 2.13$ & $57.64 \pm 2.47$ & $60.52 \pm 2.11$ & $59.14 \pm 2.23$ \\
\hline Neutrophils (\%) & $28.31 \pm 0.86$ & $34.11 \pm 1.31$ & $33.42 \pm 0.976$ & $35.63 \pm 1.12$ & $32.53 \pm 0.874$ & $30.63 \pm 0.923$ \\
\hline
\end{tabular}


Table 6: Effect of heavy metals pollution on urea and creatinine $(\mathrm{mg} / \mathrm{dl})$ of Nile tilapia fish at different farms.

$\begin{array}{lllllll}\text { PARAMETERS } & \begin{array}{l}\text { Control } \\ \text { group((speia } \\ \text { Ifarm from } \\ \text { Kafr Elsheik) }\end{array} & \begin{array}{l}\text { Talkha } \\ \text { Drainage }\end{array} & \begin{array}{l}\text { Elgerpy in } \\ \text { Ras Elbar }\end{array} & \begin{array}{l}\text { Manzala } \\ \text { Lake }\end{array} & \begin{array}{l}\text { Nile of } \\ \text { Sherbin }\end{array} & \begin{array}{l}\text { Diast } \\ \text { Drainage }\end{array} \\ \text { Creatinine } & 1.21 & 2.79 & 1.52 & 2.21 & 1.40 & 1.73 \\ & \pm 0.08^{\mathrm{d}} & \pm 0.11^{\mathrm{a}} & \pm 0.08^{\text {cd }} & \pm 0.08^{\mathrm{b}} & \pm 0.12^{\mathrm{cd}} & \pm 0.11^{\mathrm{c}} \\ & & & & & \\ \text { Uric acid } & 3.130 & 5.453 & 3.88 & 4.107 & 3.718 & 4.011 \\ & \pm 0.09^{\mathrm{c}} & \pm 0.16^{\mathrm{a}} & \pm 0.05^{\mathrm{b}} & \pm 0.17^{\mathrm{b}} & \pm 0.07^{\mathrm{b}} & \pm 0.14^{\mathrm{b}}\end{array}$

Means in the same row with different superscripts are significantly different at ( $P \leq 0.05)$.

Table 7: Effect of heavy metals pollution on Lysozymes activity $(\mathrm{mg} / \mathrm{ml})$ in serum of Nile tilapia fish in different localities of Delta Egypt showing Lysozymes activity $(\mathrm{mg} / \mathrm{ml})$ in serum of Nile tilapia fish.

$\begin{array}{ccccccc}\begin{array}{c}\text { Lysozymes } \\ \text { activity }\end{array} & \begin{array}{c}\text { Control } \\ \text { group((speial } \\ \text { farm from } \\ \text { Kafr Elsheik }\end{array} & \begin{array}{c}\text { Talkha } \\ \text { Drainage }\end{array} & \begin{array}{c}\text { Elgerpy in } \\ \text { Ras Elbar }\end{array} & \begin{array}{c}\text { Manzala } \\ \text { Lake }\end{array} & \begin{array}{c}\text { Nile of } \\ \text { Sherbin }\end{array} & \begin{array}{c}\text { Diast } \\ \text { Drainage }\end{array} \\ \text { Mean } \pm \text { SE } & \begin{array}{l}373.45 \\ \pm 1.15^{\mathrm{a}}\end{array} & \mathbf{3 4 7 . 3 3} & \mathbf{3 5 5 . 7 7} & \mathbf{3 5 1 . 0 3} & \mathbf{3 5 6 . 8 6} & \mathbf{3 5 2 . 8 5} \\ & \pm 1.68^{\mathrm{c}} & \pm 2.03^{\mathrm{b}} & \pm \mathbf{1 . 6 3}^{\mathrm{bc}} & \pm 1.27^{\mathrm{b}} & \pm 1.45^{\mathrm{bc}}\end{array}$

Means in the same row with different superscripts are significantly different at $(P \leq 0.05)$.

Table 8: Effect of lead pollution on Glutathione-S-transferase (GST) gene expression in liver sample of Nile tilapia fish samples in different localities of Delta Egypt.

\begin{tabular}{|c|c|c|c|c|}
\hline Group & Mean & Std. Error & Minimum & Maximum \\
\hline Gsa1 & & & & \\
\hline $\begin{array}{l}\text { (control group) } \\
\text { (speial farm from kafr elsheik) }\end{array}$ & $1.00^{d}$ & .057 & .90 & 1.10 \\
\hline $\begin{array}{l}\text { Gsa2 } \\
\text { (Elgerpy In Ras Elbar group) }\end{array}$ & $7.33^{c}$ & .45 & 6.58 & 8.16 \\
\hline $\begin{array}{l}\text { Gsa3 } \\
\text { (manzala lake }\end{array}$ & $9.96^{b}$ & .41 & 9.18 & 10.58 \\
\hline Group) & & & & \\
\hline $\begin{array}{l}\text { Gsa4 } \\
\text { (talkha drainage } \\
\text { Group) }\end{array}$ & $12.77^{a}$ & .39 & 12.13 & 13.50 \\
\hline
\end{tabular}




\section{DISCUSSION}

The usage of biomarkers for pollution within fish (Oreochromis. niloticus) is efficient measure for evaluation ecosystem and studying of negative influence[20].Due to the insufficiency of protein sources for the vast increased population in the third world countries, fish farming has gained popularity as alternative source of a cheap protein. However, in several areas of these countries they use recycled water for agricultural drainage, industrial drainage or even sewage. Thes e sources of recycled wa ter comprise a health challenge, either to the fish raised in it, to the ecosystem or to the human consuming the fish.Therefore, water is the most natural resource which presents on our planet and is important for survival and progression of modern technology. Thus, rapid industrialization is one of key reasons for aquatic pollution. Discharged waste water has been used in different regions of the world for fish raising [21].

In the current resea rch the concentration of lea d within va rious organs (muscles, liver, kidney, gills) of Nile tilapia fish (Oreochromis. niloticus) in different localities in Delta Egypt as showing in table (1) There was very highly significant increase in lead level in G2 in organs of Nile tilapia fish (Oreochromis. niloticus)) more than $\mathrm{G} 3, \mathrm{G} 4, \mathrm{G} 5, \mathrm{G} 6$ is an indication for the presence of very high level of pollution in this area due to industrial waste effluents discharged from Talkha factory of fertilizers, Increasing lead level in G4 more than $\mathrm{G} 3, \mathrm{G} 5, \mathrm{G6}$, is a nindication also for the presence of very high level of pollution in this a rea due to agricultural and industrial waste effluents discharged from factories around Manzala lake..These results agree with the findings of [22] who found that level of trace el ements within different tissues of fish mirrors amount of water pollution within

Due to industrial waste effluents discharged from Talkha factory of fertilizers, increasing cadmium level in G4 more than G3, G5, G6, is an indication also for the presence of very high level of pollution in the area of Manzala lake due to agricultural and industrial waste effluents discharged from factories around Manzala Lake. Lake Manzala is a major lake within Egypt because of its extents and economic value. The findings of current research show that Lake Manzala is very contaminated with Cupper, Cadmium, and lead because of constant excretion of various pollutants into it. Our findings are in agreement with [29].

Concentration of cupper in different organs (muscles,liver,kidney,gills) of Nile tilapia fish (Oreochromis.niloticus) within different localities in Delta Egypt as showing in table (3) there is significant rise in cupper level in different organs comparing to the control group (G1) and this an indication for the presence of heavy metals pollution , Increasing copper level in G2 more than $\mathrm{G} 3, \mathrm{G} 4, \mathrm{G} 5, \mathrm{G} 6$ is an indication for the presence of very high level of pollution in this a rea due to ind ustrial waste effluents discharged from Talkha factory of fertilization, Increasing cupper level in $\mathrm{G} 4$ more tha $\mathrm{G} 3, \mathrm{G5}, \mathrm{G6}$, is a n indication also for the pres ence of very high level of pollution in this area due ecosystem where these fish exist. [23] concluded that if environment obtains foreign pollutants like metals, the orga nisms existing within it can absorb pollutants from water or/and food and deposit it into their bodies. . .Our results also agree with [24] who found that concentrations of $\mathrm{cu}, \mathrm{pb}, \mathrm{cd}$ ,within gills and liver of $C$. chanos obtained from polluted areas exhibited increasing concentrations for metals in comparison to samples from lower polluted of Kaattuppalli Island waters.

The highest concentration of lead was found in liver and kidney but the lowest lead concentration was found in muscles, our results is in agreement with [25] who found that the muscles got the least levels of entire assessed metals excluding Cupper was documented with the least level s within gills of $C$. pulchellus. These results agree withour study since we found that muscles of fish got the least deposition of heavy metalsas [26] .The highest level of tested metals within liver tissue could become increased because of role of liver in detoxification and protection from heavy metals [27].

Within current research concentration of cadmium within various organs (muscles, liver, kidneyand gills) of Nile tilapia fish (Oreochromis.niloticus) in different localities in Delta Egypt as showing in table (2) there was significant increase in cadmium level in organs of Nile tilapia fish (Oreochromis O.niloticus) comparing to the control group(G1)and this an indication for the presence of heavy metals pollution, $\mathrm{Cd}$ could mediate hematological and liver problems, further changes within hema tological indices [28] .Increasing cadmium level in $\mathrm{G} 2$ more tha $\mathrm{G} 3, \mathrm{G} 4, \mathrm{G} 5, \mathrm{G} 6$ is an indication for the presence of very high level of pollution in this area .

to a gricultural a nd industrial wa ste effluents discharged from Factories a round Manzala lake. Our findings agree with [29] who found that Cupper within tissues of fish in water of lake Manzala existed in greater levels than from those of reference values present in places for drinking and irrigation usages. Concerning liver\& kidney there is very highly remarkable $(P \leq 0.05)$ rise within cupper concentration.

The haematological analysis of blood samples showed major decline in RBCs, $\mathrm{Hb}$ and PCV valued. Decrease within RBCs synthesis within hematopoietic organ due to a ccumulation of heavymetals at higher concentrations within tissue and because of intrahepatic and intrasplenic bleeding. Decrease in RBCs may be due to decrease in RBCs synthesis within BM by heavy metals. A study showed that fish hematological difference because of metals exposure happens after osmotic variations which lea d to hemodilution or hemoconcentrations. This finding a grees with ea rlier study that showed important decline of $\mathrm{Hb}$ and $\mathrm{PCV} \%$ in fresh water fish affected with high concentration of heavy metals [30].

As shown in table (4) our result indicates a significant( $P \leq$ 0.05 ) decrease in total leukocytic count than control group but non-significant difference was found between G1\&G3 
and also between $G 2 \& G 5$, our result agree with [12] who found decrease in total WBCs in all studied groups than control group, ceptibility to sepsis. while stimulation of immune system leads to upsurge of lymphocytes via tissue injury, a prolonged stimulus can lead to exhaustion of this capacity, causing decline within lymphocytic and so total WBCs [31]. The cellular components of fish immunity involve Iymphocytes and neutrophils [32],. As shown in table (5), in our study ALT and AST activities increased ( $P \leq 0.05$ ) significantly within entire groups comparing with control group. The present findings are supported by [33] as they identified rise of AST and ALT activities in stressed fish because of liver damage or augmented production of these enzymes via liver. Enzymes, like a minotransferases can rise within blood because of leak from cells within damaged tissues and soact as indicators of particular or multiple organ impairment [34]..

As shown intable (5), in our result there is significant ( $P \leq$ 0.05) decrease in total proteins within entire groups comparing to the control group but non-significant difference between G2 and G3,our results agree with[35] who found that decline within protein content as observed within fish tissues of studied species, and he attributed it to metabolic usage of ketoacids to gluconeogenesis pathway for production of glucose.

Plasma creatinine and uric acid act as indicators of GFR and renal impairment [36]. Lower concentrations of creatinine and uric acid have no importance, but their rise refers to numerous dysfunctions within kidney [37]. Lysozyme exist within lysosomes of neutrophils and macrophages and is secreted to circulation from these cells [38] As shown in table (7) Lysozyme a ctivity in serum samples of Nile tilapia fish were (,in our result there is significant ( $P \leq$ 0.05 ) decrease within lysozymes in entire groups than control group. The maximum activity of lysozymes in plasma of Nile tilapia was found at control group and mi nimum a ctivity was found at G1.

Regarding lysozyme activity, the present results are in agreement with that of Witeska [39].who found that lysozyme activity with in common carp serum is reduced after exposure to heavy metals that propose heavy metals can increase liability of common carp to disorders because of reduced innate immune response.

GSTs are major phase II, GSH-dependent ROS- and electrophilic xenobiotic-detoxifying enzymes [40]. GST gene expression in liver of Nile tilapia fish (O.niloticus) the mean values of $(1.0,7.3,9.9$, and 12.7) for control group, G2,G3,G1, respectively.

\section{Conclusion}

From the present study, we can conclude that agricultural drainage, industrial drainage and lakes are considered the most polluted location that affect fish tissues and so become a threat to human. So, we advise to follow major principles that underlie strategies so treatment of agricultural drainage and sewage water should be carried out before draining in natural water areas, that efforts are focused on issues that pose the greatest risk. The government must establish fish safety requirements, and disposal of factory waste safely away from water drainage then ensure that the requirements are through a range of regulatory measures and frequent examination of marketed fish.

\section{Conflict of interest}

The a uthors declare that they have no conflict of interest.

\section{Research Ethics Committee Permission}

All methods used in the study were performed in accordance with the ethical guidelines and recommendations of the Research Ethics Committee, Faculty of Veterinary Medicine, Mansoura University.

\section{Authors' contribution}

N. M designed the model and analyzed the data; A.E carried out the experimental works. O. O drafting the manuscript; T. M. revised the manuscript

\section{REFERENCES}

[1] Saleh YS, Marie M-AS. Assessment of metal contamination in water, sediment, and tissues of Arius thalassinus fish from the Red Sea coast of Yemen and the potential human risk assessment. Environ Sci Pollut Res 2015;22:5481-90. https://doi. org/10.1007/s11356-014-3780-0

[2]Authman MM, Zaki MS, Khallaf EA, Abbas HH. Use of fish as bio-indicator of the effects of heavy metals pollution. J Aquac Res Dev 2015;6:1-13. https://doi.org/10.4172/2155-9546.1000328

[3] Bauvais C, Zirah S, Piette L, Chaspoul F, Domart-Coulon I, Chapon V, et al. Sponging up metals: bacteria associated with the marine sponge Spongia officinalis. Mar Environ Res 2015;104:20-30. https://doi.org/10.1016/j.marenvres.2014.12.005

[4] Wagner A, Boman J. Biomonitoring of trace elements in muscle and liver tissue of freshwater fish. Spectrochim Acta Part B At Spectrosc 2003;58:2215-26. https://doi.org/10.1016/j.sab.2003.05.003

[5] Schwarzenbach RP, Egli T, Hofstetter TB, Von Gunten U, Wehrli B. Global water pollution and human health. Annu Rev Environ Resour 2010;35:109-36. https://doi.org/10.1146/annurev-environ-100809125342

[6] Lamas S, Fernández J, Aboal J, Carballeira A. Testing the use of juvenile Salmo trutta L. as biomonitors of heavy metal pollution in freshwater. Chemosphere https://doi. org/10.1016/j.chemosphere.2006.10.040

[7] Al-Yousuf M, El-Shahawi M, Al-Ghais S. Trace metals in liver, skin and muscle of Lethrinus lentjan fish species in relation to body length and sex. Sci Total Environ 2000;256:87-94. https://doi.org/10.1016/S00489697(99)00363-0

[8] Polat F, Akın Ş, Yıldırım A, Dal T. The effects of point pollutants originated heavy metals (lead, copper, iron, and cadmium) on fish living in Yeşilırmak River, Turkey. Toxicol Ind Health 2016;32:1438-49. https://doi.org/10.1177/0748233714565709

[9] Omar WA, Saleh YS, Marie M-AS. Integrating multiple fish biomarkers and risk assessment as indicators of metal pollution along the Red Sea coast of Hodeida, Yemen Republic. Ecotoxicol Environ Sa 2014;110:221 31. https://doi.org/10.1016/j.ecoenv.2014.09.004

[10] Idriss A, Ahmad A. Heavy metal concentrations in fishes from Juru River, estimation of the health risk. Bull Environ Contam Toxicol 2015;94:204 8. https://doi.org/10.1007/s00128-014-1452-x

[11] Sfakianakis D, Renieri E, Kentouri M, Tsatsakis A. Effect of heavy metak on fish larvae deformities: a review. Environ Res 2015;137:246-55. https://doi.org/10.1016/j.envres. 2014.12.014

[12] Fazio F, Piccione G, Tribulato K, Ferrantelli V, Giangrosso G, Arfuso F, et al. Bioaccumulation of heavy metals in blood and tissue of striped mullet in two Italian lakes. J Aquat Anim Health2014;26:278-84. https://doi.org/10.1080/08997659.2014.938872

[13] Birungi Z, Masola B, Zaranyika M, Naigaga I, Marshall B. Active biomonitoring of trace heavy metals using fish (Oreochromis niloticus) as bioindicator species. The case of Nakivubo wetland along Lake 
Victoria. Phys Chem Earth 2007;32(15-18):1350-8. https://doi.org/10.1016/j.pce.2007.07.034

[14] Capar MSG. Metals and other elements. J AOAC, 601401-1408. 1977.

[15] Obodo G. The bioaccumulation of heavy metals in fish from the lower Reaches of River Niger. J Chem Soc Nigeria 2002;27:173-6.

[16] Stirn J. Manual of methods in aquatic environment research. Part 8. Ecological assessment of pollution effects (Guidelines for the FAO GFCM/UNEP Joint Coordinated Project on Pollution in Mediterranean). FAO fish tech paper 1981;209:1-190.

[17] Hassanin AA, Kaminishi Y, Osman MM, Abdel-Wahad ZH, El-Kady MA Itakura T. Development and application of a real-time quantitative PCR assay for determining expression of benzo-apyrene-inducible cytochrome P450 1A in Nile tilapia (Oreochromis niloticus). Afr J Biotechnol 2009;8.

[18] Ellis AE. Lysozyme Assays. In: Stolen, J.S., Fletcher, T.C., Anderson, D.P., Roberson, B.S. and Van Muiswinkel, W.B., Eds., Techniques in Fish Immunology Fair Haven, SOS Publications, Fair Haven, 1990;101-103.

[19] Keuls M. The use of the "studentized range" in connection with an analysis of variance. Euphytica 1952;1:112-22. https://doi.org/10.1007/BF01908269

[20] Lasheen MR, Abdel-Gawad F, Alaneny AA, bary HMHA. Fish as bio indicators in aquatic environmental pollution assessment: A case study in abu-rawash Area, Egypt. World Appl Sci J 2012;19:265-75.

[21] Zeitoun MM, Mehana E. Impact of water pollution with heavy metals on fish health: overview and updates. Glob Vet 2014;12:219-31.

[22] Bream AS, Amer MS, Haggag AA, Mahmoud MA. Valuation of water pollution using enzymatic biomarkers in aquatic insects as bioindicators from El-Mansouriya stream, Dakahlia, Egypt. IJARBS 2017;4:1-15. https://doi.org/10.22192/ijarbs.2017.04.03.001

[23] Tchounwou PB, Yedjou CG, Patlolla AK, Sutton DJ. Heavy metal toxicity and the environment. Exp Suppll: Springer; 2012. p. 133-64. https://doi. org/10.1007/978-3-7643-8340-4_6

[24] Rajeshkumar S, Mini J, Munuswamy N. Effects of heavy metals on antioxidants and expression of HSP70 in different tissues of Milk fish (Chanos chanos) of Kaattuppalli Island, Chennai, India. Ecotoxicol Environ Saf 2013;98:8-18. https://doi. org/10.1016/j.ecoenv.2013.07.029

[25] Al-Ghanim KA, Abdelatty M, Abdelfattah L, Mahboob S. Differential uptake of heavy metals by gill, muscles and liver of four selected fish species from Red Sea. Pak J Zool 2015;47.

[26] Bawuro AA, Voegborlo RB, Adimado AA. Bioaccumulation of Heavy Metals in Some Tissues of Fish in Lake Geriyo, Adamawa State, Nigeria. J Environ Public Health. 2018;2018:1854892. https://doi.org/10.1155/2018/1854892

[27] Al-Kahtani MA. Accumulation of heavy metals in Tilapia fish (Oreochromis niloticus) from AL-Khadoud spring, AL-Hassa, Saudi Arabia. Am J Appl Sci 2009;6:2024. https://doi. org/10.3844/ajassp.2009.2024.2029

[28] Javed, Usmani. Impact of heavy metal toxicity on hematology and glycogen status of fish: a review. Proc Natl Acad Sci India Sect B Biol Sci 2015;85:889-900. https://doi.org/10.1007/s40011-014-0404-x

[29] Badawy M, Wahaab R, Abou Waly H. Petroleum and chlorinated hydrocarbons in water from Lake Manzala and associated canals. Bull Environ Contam Toxico 1995;55. https://doi.org/10.1007/BF00203018

[30] Guedenon P, Edorh PA, Hounkpatin AS, Alimba CG, Ogunkanmi A, Nwokejiegbe EG, et al. Haematological study of Clarias gariepinus exposed to chronic and subchronic doses of cadmium, mercury and combined cadmium and mercury. Sci Nat 2012;4:2-19.

[31] Adeyemo O, Adedeji O, Offor C. Blood lead level as biomarker of environmental lead pollution in feral and cultured African catfish (Clarias gariepinus). Niger Vet J 2010;31. https://doi. org/10.4314/nvj.v31i2.68957

[32] Castro R, Jouneau L, Tacchi L, Macqueen DJ, Alzaid A, Secombes CJ, et al. Disparate developmental patterns of immune responses to bacterial and viral infections in fish. Sci Rep 2015;5:15458. https://doi.org/10.1038/srep15458

[33] Wu RS, Pollino CA, Au DW, Zheng GJ, Yuen BB, Lam PK. Evaluation of biomarkers of exposure and effect in juvenile areolated grouper (Epinephelus areolatus) on foodborne exposure to benzo [a] pyrene. ET\&CJ 2003;22:1568-73. https://doi.org/10.1002/etc.5620220720

[34] Boyd J. The mechanisms relating to increases in plasma enzymes and isoenzymes in diseases of animals. Vet Clin Pathol 1983;12:9-24. https://doi.org/10.1111/j.1939-165X.1983.tb00609.x
[35] Sobha K, Poornima A, Harini P, Veeraiah K. A study on the biochemical changes in freshwater fish Catla catla exposed to the heavy metal toxicant, cadmium chloride. J Sci Eng Technol 2007;1:1-11 https://doi. org/10.3126/kuset.v3i2.2890

[36] Ismail HTH, Mahboub HHH. Effect of acute exposure to nonylphenol on biochemical, hormonal, and hematological parameters and muscle tissues residues of Nile tilapia; Oreochromis niloticus. Vet World. 2016;9:616. https://doi.org/10.14202/vetworld.2016.616-625

[37] Maxine M, Benjamin B. Outline of veterinary clinical pathology. Colorado state university, printed in India at Rakha printers PVT. LDT New Delhi. 1985.

[38] Murray C, Fletcher T. The immunohistochemical localization of lysozyme in plaice (Pleuronectes platessa L.) tissues. J Fish Biol 1976;9(4):329-34. 8649.1976.tb04681.x

[39] Witeska M. Stress in fish-hematological and immunological effects of heavy metals. J Ichthyol. 2005;1:35-41.

[40] Meierjohann S, Walter RD, Müller S. Regulation of intracellular glutathione levels in erythrocytes infected with chloroquine-sensitive and chloroquine-resistant Plasmodium falciparum. Biochem J 2002;368(Pt 3):761. https://doi. org/10.1042/bj20020962 